Didáctica Geográfica nº 19,2018,pp. 77-101

ISSN: 0210-492-X

D.L: M-3736-2014

\title{
FIELDWORK IN GEOGRAPHY EDUCATION: AN EXPERIENCE IN INITIAL TEACHER TRAINING PROGRAM
}

\author{
Maria Helena Esteves ${ }^{1}$; Maria João Hortas²; Luís Mendes ${ }^{3}$
}

Recibido: 17/07/2017

Aceptado: 25/09/2017

\begin{abstract}
:
Fieldwork in geography education is an important activity in terms of promoting the development of geographical knowledge and skills that go beyond school learning. The way this contact with the real world is done has evolved from the traditional school visit (fieldtrip) to models where students' involvement is deeper representing the contribution of several educational theories in geography educational practices. This paper presents a rational about fieldwork implementation as a methodology of data collection used in research undertaken at a local scale, included in a program of geography initial teacher training. As the experience took place in an urban area, the paper includes a conceptual framework about the potential of the city as a research area in terms of fostering critical thinking and the formation of geographically competent citizens.
\end{abstract}

1 Professor at the Instituto de Geografia e Ordenamento do Território and Researcher in the Centro de Estudos Geográficos, Instituto de Geografia e Ordenamento do Território da Universidade de Lisboa. E-mail: me@campus.ul.pt.

2 Professor and Vice-President of the Escola Superior de Educação de Lisboa and Researcher in the Centro de Estudos Geográficos, Instituto de Geografia e Ordenamento do Território da Universidade de Lisboa. E-mail: mjhortas@eselx.ipl.pt.

3 Guest Lecturer at Escola Superior de Educação de Lisboa and Researcher in the Centro de Estudos Geográficos, Instituto de Geografia e Ordenamento do Território da Universidade de Lisboa. E-mail: luis.mendes@campus.ul.pt. 


\section{KEYWORDS:}

Fieldwork, geography education, initial teacher training, critical spatial thinking.

\section{RÉSUMÉ:}

Dans le cadre de l'éducation géographique, le travail sur le terrain permet le développement d'un ensemble de connaissances et de compétences qui vont audelà des murs de l'école. La façon dont ce contact avec le réel se produit a évolué à partir de la traditionnelle visite d'étude (la visite sur le terrain) vers des modèles où la participation des étudiants à la réalité s'est approfondie et reflète aussi l'influence du développement de divers mouvements éducatifs sur les pratiques de l'éducation géographique. Afin de mieux comprendre cette réalité, nous avons choisi, comme objet d'analyse, une expérience d'apprentissage, réalisée dans le cadre de la formation initiale des enseignants, basée sur l'utilisation de la pratique de terrain comme méthode de collecte d'information pour l'étude de l'environnement local. Comme l'expérience a eu lieu dans des zones urbaines, l'ensemble conceptuel intègre une réflexion centrée sur la ville comme ressource potentialisatrice de la pensée spatiale critique et de la formation d'un citoyen géographiquement compétent.

\section{MotS-CLÉS:}

Travail de terrain, éducation géographique, formation initiale des enseignants, pensée spatiale critique.

\section{RESUMEN:}

Como parte de la educación geográfica, el trabajo de campo permite el desarrollo de un conjunto de conocimientos y habilidades que van más allá de las paredes de la escuela. La forma de poner en práctica este contacto con la realidad ha evolucionado a partir de la tradicional visita de estudio (la excursión al campo) para los modelos en los que la participación de los estudiantes con la realidad se ha profundizado y también representa una evolución en la forma como los distintos paradigmas de formación tienen influido en las prácticas de la educación geográfica. Movilizamos, así como un objeto de reflexión, una experiencia de aprendizaje sostenida en el uso del trabajo de campo como metodología de recopilación de información para el estudio del medio ambiente local, llevado a cabo en la formación inicial de los educadores/maestros. Debido a que la experiencia se llevó a cabo en medio urbano, el cuadro conceptual integra una reflexión centrada en la ciudad como recurso potenciador del pensamiento espacial crítico y de la formación de un ciudadano geográficamente competente. 


\section{Palabras clave:}

Trabajo de campo, educación geográfica, formación inicial de educadores/maestros, pensamiento espacial crítico.

\section{Resumo:}

Como parte integrante da educação geográfica, o trabalho de campo possibilita o desenvolvimento de um conjunto de saberes e competências que extravasam os muros da escola. A forma como este contacto com o real se efetiva tem evoluído desde a tradicional visita de estudo (a excursão ao campo) para modelos onde o envolvimento dos estudantes com a realidade se tem aprofundado e representa igualmente um desenvolvimento na forma como as várias correntes educativas têm influenciado as práticas da educação geográfica. Mobilizamos, assim, como objeto de reflexão, uma experiência de aprendizagem sustentada no recurso ao trabalho de campo como metodologia de recolha de informação para o estudo do meio local, levada a cabo na formação inicial de professores. Porque a experiência decorreu em meio urbano, o conjunto concetual integra uma reflexão centrada na cidade como recurso potencializador do pensamento espacial crítico e da formação de um cidadão geograficamente competente.

\section{Palavras-chave:}

Trabalho de campo, educação geográfica, formação inicial de professores, pensamento espacial crítico.

\section{INTRODUCTION}

This paper intends to be a reflection on the importance of fieldwork in geographic education. As an integral part of Geography learning, fieldwork enables the development of skills and knowledge impossible to learn within school walls. This contact with reality has evolved from the traditional study tour (the field trip) to models where students' involvement is deeply involved with the real world and it is a consequence of how the different schools of geography have influenced practices in geographic education.

In this context, our object of analysis is a learning experience using fieldwork as a methodology for collecting data in the study of the local environment. This experience took place in Bairro Alto, a central area in Lisbon, and was part of the formative evaluation of the curricular unit of Geography of Portugal, a course of the Degree in Basic Education of the Superior School of Education of Lisbon in the academic year of 2011 / 2012. Using techniques of location, data collection and direct observation of local economic activities, and working in groups of up to five elements, students were requested to students mobilize and broaden skills in the field of observation, reading and 
analysis of geographic phenomena intrinsic in urban areas organization (urban economy, urban dynamics and patterns of location / distribution). The methodological line of the fieldwork and other educational resources provided by the teachers and those created by the students, will be described and analyzed.

The analysis of this experience will be framed by a theoretical reference around the different approaches of fieldwork, in the different perspectives of the geographical science. Moreover, as the experience took place in an urban setting, the conceptual framework integrates a reflection about the city as a resource that fosters critical spatial thinking and the formation of geographically competent citizens.

The way fieldwork integrates geographic education is framed by different perspectives and objectives associated with it. Whether viewed as a traditional field visit or in a perspective more related to research methodology, fieldwork's importance in geographical education is unquestionable, representing a moment of testing of the most theoretical approaches, developing the perception about the real and thus articulating theory and practice. Our paper will address some of the most relevant aspects of fieldwork in geographical education to present some examples of how recent perspectives have been developed and sustain practices dealing directly with real problems, namely in urban environments. The activities presented were developed in fieldwork as part of the initial formation of educators / teachers and they will illustrate the pertinence of a geographical education that considers fieldwork as an important methodology of knowledge development for future professionals in the educational area.

\section{THE TRADITIONAL APPROACH IN GEOGRAPHY FIELDWORK: THE SCHOOL TRIP TO THE COUNTRYSIDE}

The excursion to the countryside to understand the landscape considering the connection between physical and human elements corresponds to a more traditional approach to fieldwork. In schools, the moment of the school trip to the field was understood as a trip to those places that had been studied in the classroom, to apply observation skills such as reading the landscape, reading maps, location skills, making schemes, with the purpose of developing a sense of place.

According to Ferreira (1995), fieldwork, as a trip to the countryside, had a major role in the learning of geographic skills, such as reading maps, using them to locate places, sketching what was visible on the horizon, and pointing out the most important aspects of the landscape. The acquisition of these basic techniques of observation and recording was essential in Geography training, only occurring in situations of contact with physical settings. 
The work developed represented an integrated view of the landscape in which the physical and human elements were interconnected. According to Job (2000) the most important objective of the more traditional study visit was to read, understand the landscape and to grasp the essence of the place. The landscape was read without questioning, as if there were no conflicts in it (environmental, social or political). The student had a relatively passive role in this type of activities.

This vision of fieldwork is associated with a regional geography that defines the region as the object of study. According to Ferreira (1990), the objective of Geography is to observe the interrelations between natural and human phenomena. The method of study of the region was thus found: based on observation, it was important to analyze the physical environment and then to understand the integration of human activities.

In Portugal, this tradition of fieldwork was very important until the 70s and 80s, when the first criticisms of this descriptive geography appeared. The descriptive dimension remains important in Geography Science, but the complexity of geographic phenomena came to query the inadequacy of this model in the sense of apprehending the true nature of the phenomena and developing possible explanations. In other words, the mere observation of the landscape was not enough to explain its the complexity. The need to bring fieldwork activities closer to scientific research arose since then.

\section{FIELDWORK IN A PERSPECTIVE OF SCIENTIFIC RESEARCH (QUANTITATIVE REVOLUTION)}

The need to carry out more rigorous work led to the definition of new objectives for the organization and implementation of fieldwork in Geography. As in any scientific research, fieldwork should be developed as a way of testing hypothesis related to geographical phenomena. This also meant that students would have a more active role in terms of participation in the tasks to be developed in fieldwork activities. They could create research hypotheses arising from their own perceptions about the geographical phenomena being studied.

Thus, fieldwork became an important part in a scientific geography anchored in quantitative methodologies. Hypothesis testing was the basis for fieldwork, so that researchers could define general models or theories explaining reality from the point of view of geography. According to Job (2000) one of the main consequences of this nomothetic view in Geography (the search for explanatory laws / models) was the decline of the ideographic tradition in Geography (in the sense that each place is unique).

The observation, discussion, and development of a sense of place do not disappear in the fieldwork thus understood as an important part of any scientific investigation, but have moved to a lesser plane by not fitting into this more rigorous and scientific model. 
For many geographers this model has become very restrictive leading in the search for alternatives to this approach to fieldwork. The main issues that arose were essentially the adequacy of these quantitative studies to the very nature of geographical studies. For some the use of this scientific methodology would have a more academic interest but would be of little application in the real world.

One of the major limitations felt was the need to separate studies on issues of physical and human geography, something that had been lost with the slightest importance given to the traditional study visit. In this sense, it was necessary to rejoin physical and human geography to understand the phenomena. In effect, since the 1990s, the impact of human activities on the environment has introduced new priorities in geographical studies. It has become necessary to rethink field work considering that analysing a problem involves different points of view, even conflict. Therefore, it was important to understand the social, environmental, and even the values present in people's attitudes.

\section{FIELDWORK AS GEOGRAPHICAL ENQUIRY}

Current problematics in geography have different nature and scale of analyses ranging from local phenomena with local impacts to a global expression (phenomena such as climate change, social issues, and problems related to pollution and sustainable development). Consequently, it was very important to develop an approach that simultaneously mobilized theories of physical and human geography to research and understand these phenomena. Doing this involved the application of a variety of geographical research methods. In this sense, fieldwork is now carried out when problematic issues / situations occur in a certain place or when different points of view involving conflict have a territorial expression. Fieldwork is understood as a method of studying problems within contexts whose characteristics are relevant to the research being developed.

From a geographical enquiry perspective, fieldwork includes different phases and methodologies that try to answer research questions related to concrete problems and contexts involving students and their perceptions. Alexandre and Diogo (1997) proposed a classification of field visits in three types corresponding to different moments of fieldwork: (i) observation / motivation to be carried out before approaching geographical contents, used as motivation for learning and leading students in the process of questioning reality; (ii) data Collection, corresponding to a phase of doing fieldwork in order to collect data to be compared with the topics addressed in the classroom; (iii) verification, carried out after learning geographical contents to validate through direct observation the issues studied in the classroom.

This idea of fieldwork includes methodologies present in other types of research but is organized around a set of enquiries for which a response is sought as in any research 
work. In this perspective, the local environment is a relevant educational resource. The city can be viewed as a didactic laboratory. Fieldwork as geographical enquiry becomes an activity that can be mobilized by teachers to deepen the teaching and learning of school geography.

\section{THE CITY AS A DIDACTIC LABORATORY AND THE LOCAL ENVIRONMENT AS A LEARNING RESOURCE}

Since the beginning of the 1970s, various innovative experiences have been developed, focusing both on the learning process and on school management, trying to improve the relation and interaction between the school and the local communities. The pertinence and scientific validity of the school-community interaction has become a relatively consensual idea. Although there are no extensive studies at the university level, it is expressed in several scientific works and in legal norms that range from educational programs to general educational policy documents (Canário, 1992, 2005; Santos e Cruz, 1995; Zabalza, 1992b; Ferreira et al., 2011).

"The school ceases to constitute an institutional structure put anywhere, always
equal and closed. It must, on the contrary, be "the school of such locality, or
neighborhood, or place". The school uses all the resources (personal, work,
institutional, cultural, sports, etc.) of its community, being therefore very interested
in that every day they are better and pressing socially for that to happen. And,
simultaneously, it is used as a cultural and formative resource by the neighbors
and organizations of that locality, neighborhood or place. In this way, there is
a crossroads of influences (from time to time, also of conflicts), but, above all,
a social and cultural dynamic is generated in which the school is not seen as
a building in the middle of the territory, but rather as a cultural agency at the
disposal of that territory" (Zabalza 1992a: 33).

Thus, one of the first themes to be included in the theoretical framework refers to an idea that it is extremely important as a guiding theoretical-scientific principle: viewing the local environment as a didactic resource and its use as a learning environment. This problematic relates to the need to narrow the gap between educational institutions and the local community. This issue is central to this study, also because it is an important activity during Geography of Portugal course as fieldwork in the city of Lisbon is an activity to be developed during the school year.

Nowadays, universities are required to play roles that exceed the mere transmission and acquisition of knowledge. Higher education has a social and civic dimension that 
must be present and developed in all courses ${ }^{4}$. The University has become an institution involved in education but has also extended its role in promoting activities that generate education in a broad sense, and in this context a strong relation with the contexts and the local community is encouraged. Universities have become "porous" and both influence and integrate the socio-cultural context in which it is bounded. The university also relativizes the socio-cultural contexts from which the students originate. This idea also implies that the creation of educational experiences, typical within a academic context, as well as in schools, is done "in" and "with" the local community, establishing and narrowing relations with it.

This rational requires a rethinking of the function and nature of the university as an institution. This new dimension considers that the university as a social agent should develop all the educational functions necessary for the integral development of the students. Therefore, a broader formative interaction with the local community is very important. We understand, as Miguel Zabalza (1992a) rightly points out, in a similar reflection about the role of schools, that the connection between the educational institution and the local is far from being a mere passive acceptance of its demands and influences. On the contrary, the relationship between the educational institution and the environment is guided by a dialectical, transactional style of openness to the outside world. The university does not become a simple reproduction of the social and cultural dynamics of its community or economy / market. The university, according to Bologna is understood as a formative and cultural agent within a context. It is also a restless, divergent social unit, both dynamic and critic (Zabalza, 2013).

The attentive appreciation of this social dimension in the elaboration and design of these strategies forced the adoption of a scientific and pedagogical position close to the school model that has been called constructivist, whose objectives, role of the teacher and role of the student vary as opposed to two other models of school: the transmissive and the technicist. Contrary to these two curricular models, in a conception of school and education that is recognized as a social and developmental act and that is oriented towards the student in its total dimension - therefore, as individual subject and member of a society - the school is an institution that can and should play an active role in the positive change of society, that is, in a sociocritical and reconstructionist conception of school and university education.

4 The Council of Europe, defending a more humanistic view of higher education, has valued the paradigm of personal and social development in the policy guidelines for higher education. To that end, it launched a project titled "The University Between Humanism and the Market - redefining its values and functions for the 21st Century" (Serrano-Velarde, 2010) at the international conference "New challenges to European higher education". 
It was in the scope of this notion of education that the learning strategies were created in the curricular unit of Geography of Portugal. These strategies were also based on the purpose of encouraging the "leap" from the transmissive teacher to a curriculum creator teacher - the one who is not stuck to the syllabus but creates thematic contents and adapts them to the situations and specificities of contexts and real situations. The teacher that is also a partner, a mediator and a manager of learning processes and situations, someone that stimulates students not only in terms of cognitive skills but also in what concerns their personal, relational and social development.

It also meant that our students were not regarded as mere "accumulators of information" unable to relate to real situations of the local environment, without critical attitudes and the ability to question real life. On the contrary they became protagonists and active participants in the building their own learning; they became thinking and reflective people along with the teacher and colleagues, involved in learning situations in the local community. The learning environment was not limited to the classroom. It is believed that a learning environment, whether at home, at university or in the community, is any set of human and material resources that promotes learning. In this perspective, a learning environment that provides growth towards the greater potential of the individual or group can be called a formative environment.

The need to reinforce the relationship between Geography of Portugal classes and Lisbon's urban environment is not only necessary but fundamental, given the nature of the experiences it can provide to students: i) structuring their civic and socio-affective maturity; ii) empowering positive attitudes and habits of relationship and cooperation, iii) triggering a conscious and responsible intervention in the surrounding reality in a perspective of building a territorial citizenship. This line of thinking is fundamental:

"To transmit geographic knowledge linked to the understanding of territories, that is, to know how to think space; and contribute to the civic education of young people, linked to the awareness of the social and political problems that, at different scales, require responsible citizenship. (...) In this context, the Geography teacher is required to be able to operate simultaneously in geographic education and citizenship education. The effectiveness of this crossing requires the mobilization of knowledge and the pedagogical reflection of geographical education, to which the often diffused demands of education for citizenship are added (Reis, 2002: 95).

The local context is a valuable educational resource, in the sense that it is believed that outside the university we also learned. It is in the daily life of the student that the student really learns to develop the critical spirit, the responsibility, the curiosity and the 
originality, a stimulus for active learning and for the fulfillment of the education for the territorial citizenship (Hugonie, 1997, Claudino, 2015, IGU-CGE, 2015), so important in the target public in question, future educators and teachers of children from 3 to 12 years of age.

To educate geographically means to help developing the necessary skills to be able to explain and think geographically (to act in the real world) and not only to describe close or distant places (Mérenne-Schoumaker, 1985; IGU-CGE, 2015). It is also important to invest in the attitudinal aspects of learning (experimental contents with affective components, decision making, affective attitudes, personal commitment) (Cachinho, 2002, 2012, IGU-CGE, 2015). This way, we are also ensuring that geography education breaks with the transmissive paradigm and becomes a constructivist school, based in active methodologies helping students to build their own knowledge (Benejam, 1992, 1996, Mérenne-Schoumaker, 1999, 2015. IGU-CGE, 2015).

In this context, it is necessary to summon the most useful didactic strategies to advance the critical geographical knowledge related to the main problems and themes of the city that are also territorial problems and require the mobilization of specific analysis skills of critical spatial thinking. However, this approach stimulates and is corroborating an engagement of thematic anchors of the contents of the Geography of Portugal in real social and urban problems. We are not only making sure that student work is polarized into areas of significant interest for students but also celebrating the social utility of the geography that is taught and made to learn in order to develop the skills necessary for territorial citizenship. A geography capable of mobilizing the students' previous representations and knowledge, in order to allow reflection on the problems that arise in the urban environment, by the way societies and their respective groups are using their space (Cachinho and Reis, 1991, Hugonie, 1989, Souto González, 2002, 2017, Cachinho, 2002, 2012, IGU-CGE, 2015).

A conceptual and thematic approach to urban space within the framework of a Geography of Portugal (only in terms of thematic contents) is still important, although clearly insufficient in the development of the spirit of critical thinking of urban space production, as evidenced by several recent researches ${ }^{5}$. As an example, Bento and Cavalcanti (2009: 1), in a reflection on the constitution of spatial knowledge regarding the city content and its role in the formation of the professional identity of the teacher, sought to understand how knowledge contributes for the formation and practice of citizenship:

5 See Souto González, 1994a, 1994b; Cavalcanti, 1998, 2008; Carlos, 1999; Oliveira, 2008; Bento and Cavalcanti, 2009; Bado, 2009; Esteves, 2010; Cavalcanti and Morais, 2011. 
"In this respect, it is up to the school Geography to effectively fulfill its task of training citizens, aware that the right to the city is a right of all. Therefore, one should not lose sight of the teacher's own formation, since the exercise of citizenship is closely linked to the knowledge of the teacher, as a subject who exercises citizenship and understands what involves the formation and practice of becoming a citizen and, in particular, to the knowledge related to the conception of the city that underlies the teaching practice of the Geography teacher. Because of this, it is important to ascertain what conception this teacher has of the city and on what theoretical basis he supports his knowledge about the city".

For this it is necessary that the teacher perceives that the purpose that should regulate the practice resides in the search to emphasize the insufficiencies of the previous ideas and attitudes of the students with respect to the understanding of the diverse contents / thematic ones in the form of territorial problems, to explain them appropriately, at the same time as he stimulates critical thinking. The action of the Geography teacher requires that it be defined no longer by manipulating the students' educational itineraries, but rather by the interest in creating educational conditions and experiences that allow them to participate actively in the process of knowledge construction and access to performances that progressively express more complex and integrated levels of cognitive and moral development in terms of spatial thinking.

The role of the teacher is that of a facilitator and guiding the conceptual and attitudinal change that occurs in the student, providing him with learning experiences that reveal the need to modify his conceptions and even values before the changes that the urban space in question has evidenced. This can only be achieved by defining the thematic contents related to the city in the form of problems or links that make the connection between previous knowledge and social spatial reality to the point that it provokes cognitive and attitudinal conflicts in the student (Is my hypothesis of explanation sufficient? Should I deepen my knowledge in this respect?), whose lack of resolution is capable of leading to the recognition of the need to correct and reconfigure his previous ideas and attitudes. Students' learning can be improved by organizing activities whose contents are potentially significant or by mobilizing materials and teaching resources that can be actively manipulated and worked on by the students themselves. We believe that this is the case of the proposed field work presented in this paper. When it is possible for them to establish relevant relations between this new material and their previous knowledge, in order to achieve a personal representation of knowledge. When one shows them how the insufficiency of the protoconcepts that persist in their scheme of knowledge does not adequately explain and intervene in the production of the present urban space: 
"In order for students to understand the spaces of their everyday life that have become extremely complex, they must learn to look at both a broader and global context of which they are all part and the elements that characterize them and distinguish their local context. I understand that, in order to achieve the objectives of this education, the place of the student should be taken into account, but with a view of building a more general framework for this student to enable him to make more critical analysis of that place" (Cavalcanti, 2008: 43).

A school geography centred in a "conflicting" urban space may trigger curiosity for problematic training experiences in real life and with real problems. In this case, several questions were raised in what concerns the neighbourhood being studied by the students. These questions resulted from the use of the territory itself and all the observable conflicts (Pinchemel, 1982, Hugonie, 1989, Cachinho, 2002, 2012, IGU-CGE, 2015). The closer problems are from students' daily life, the more meaningful they will be. The problems researched affected their daily lives and the society in which they live and allowed them to establish relationships with what was happening in the territory of the other (Hugonie, 1992, 1997; Cachinho, 2002; 2012; IGU-CGE, 2015). A problematizing geography of the real implies knowing how to think of space, means raising key questions in order not only to recognise it, but also to discuss it, to think about it, to understand it and to act on it.

\footnotetext{
"Studying Geography is understanding the processes that engender human life in space and time. It is to have an idea of the ideological and political position that is assumed, thinking the relations that are established with the others, with the knowledge, with the objects. Concerning the study of the city and life in the city, especially, it is a question of understanding the ideals implicit in the way of its social and spatial organization and of learning about the possible ways of intervening and transforming it in it" (Bado 2009: 28).
}

This fact is fundamental to educate citizens, to form, from the concrete reality of urban life, within the framework of permanent values in Portuguese society in general, and of urban society in particular; aiming at fostering a creative and interested spirit in the resolution of urban problems at multiple scales, typical of what we intend to increase when we refer to School Geography as an instigator of a geographic (multiscalar) reasoning that can start from the organization of life in the city. This is only possible through the adoption of a "critical pedagogy of the problem" that gives voice to the students, involving them in processes of reflection and discovery, which, in principle, are more 
successful, guarantee the recognition of true learning and the need for transformative intervention in the surrounding environment, at multiple scales (Claudino, 2015, IGUCGE, 2015, Souto González, 2017).

The constructivist perspective suggests that more than drawing knowledge from reality, it only takes on meaning as we construct it. The construction of meaning, whether from a text, from field work, from a given document, from a dialogue, or from any other type of direct experience ${ }^{6}$; always implies an active process of internal formulation of hypotheses and testing in order to valid them. If the proposed solution is rejected and the situation considered to be "meaningless", it intends to proceed with new hypotheses. Taking into account that knowledge is never isolated but forming coherent systems, learning does not suppose a simple modification of an isolated concept, but rather the restructuring of the previous conceptual schema by a different one. In this context, it is understood that learning should focus on solving real problems, from which it can be deduced that the direct teaching of concepts will probably not be productive, since the student may retain protoconcepts or prejudices, giving rise to an incomplete knowledge. In the latter case, students are mainly concerned with memorizing the definitions of concepts, even if they often do not perceive their meaning, to reproduce them in the evaluation test and forget immediately.

Thus, concepts should never be given or finished, on the contrary, they should be understood according to an act of learning as a continuous process of reconceptualization, re-elaboration and deepening of the known. The concepts must be subjected to a permanent reconstruction, in a spirit of discovery and investigation (Mérenne-Schoumaker, 2015). It is assumed that the logic of the scientific research process is transposed into the classroom. We will not develop here the investigative model that, as the designation itself indicates, focuses on the process of school research, that is, on the process aimed at detecting problems, formulating them and solving them, being understood as a problem all the difficulty that can not be overcome automatically, requiring the implementation of targeted activities aimed at its resolution. A "problematizing geography of the real" implies knowing how to think space, means putting key questions in order not only to know it, but also to discuss it, to think it, to understand it in order to act on it. The problems must imply a choice between two or more possibilities of solution as it is advocated by the postmodern school with respect to the plurality and diversity of interpretations. The problem-solving methodology fuels the students' curiosity and discovering spirit because it focuses on something that affects their real and everyday life, something for which they want to find a solution. It is reflecting on a major problem that affects students, who learn to ask questions and establish

${ }^{6}$ Many of the working groups frequently used unstructured interviews and non-participant observation in the studied area of Lisbon. 
conjectures and hypotheses about them, as well as critically question the information that is provided to them or that they collect through documentary research and fieldwork.

\title{
6. FIELDWORK THROUGH A FUNCTIONAL SURVEY IN BAIRRO ALTO, LISBON
}

A review of the vast, recent (and not so recent) national and international literature that deals with field work in school geography ${ }^{7}$ quickly allows us to conclude some of the valences that this methodology takes to improve the teaching-learning process of territory science. From what has been mentioned above, it is pointed out that the experience of fieldwork in Geography classes can be an important ally of the educator by contributing to the active construction of the geographic view of the students, both with a view to deepening the investigative method and critical thinking of the space as a motor for the (re) construction of values and attitudes, but also of specific procedures and competences of geographic science, of undoubted contribution to the development of "knowing space" and a territorial citizenship, as Karina Neves ( 2015: 12-13) puts:

\begin{abstract}
"Through activities involving in situ identification and interpretation of phenomena studied in the classroom in various areas of knowledge, the use of fieldwork methodology can, on the one hand, promote the development and improvement of research procedures - component knowledge in any discipline. The use of this methodology allows the initiation of scientific research and the handling of certain instruments such as plans, maps, sketches, compasses, among others, which play a fundamental role in geographic practice and whose domain contributes to the construction of student autonomy. On the other hand, the use of this methodology can also promote a greater meaning of the contents and a closer approximation of the reality of the students. In addition to the contextualisation contributing to the development of positive attitudes towards science through the recognition of its social importance, it still favors the learning of conceptual contents, valuing and stimulating the interaction with students' previous knowledge".
\end{abstract}

7 Plans (1967), Graves (1978), Debesse-Arviset (1978), Ogallar (1996), Alexandre and Diogo (1997), Souto González (1998), Mérenne-Schoumaker (1999), Lambert and Balderstone (2000), Rodrigues and Otaviano (2001), Silva (2004), Serpa (2006), Alentejano and RochaLeão (2006), Lacoste (2006), Kaiser (2006), Matheus (2007), Straforini (2008), Galvani and Beserra de Lima (2008), Souza and Chiapetti (2012), Justen-Zancanaro and Carneiro (2012), Castellar, Cavalcanti and Callai (2012), Dourado (2013), Evangelista (2014), Neves (2015), Lacerda, Borges and Oliveira (2015), Alcântara (2015), in addition to other references already mentioned in this paper. 
In this process of valuing previous knowledge, in addition to the concepts of place and landscape, during the course of the field work they assume a prominent position in the analysis of the geographical space, by emphasizing, respectively, the dimensions of materiality as of the symbolic of the place, fieldwork methodology is an excellent opportunity to (re) signify the student's knowledge about space, as well as an instrument for the development of skills related to geographic know-how.

Having presented this theoretical framework, we will describe a learning experience involving fieldwork in Bairro Alto, in Lisbon ${ }^{8}$, which was used to accomplish, in a coherent didactic praxis, the theoretical principles stated above. Through activities of location, data collection and direct observation of economic activities in the local reality, students were invited to mobilize observation skills, analysis of geographical phenomena within the urban economy, its characteristics, dynamics and patterns of location / distribution.

The objective of this social and functional analysis was to: i) apply the theoretical principles and concepts underlying orientation and geographical location; ii) developing skills in observation, understanding and investigation of geographical phenomena; iii) understanding the characteristics, dynamics and internal organization of urban space; iv) study the economic activities in an urban area of Lisbon and, v) to contact with the local reality and problems, through fieldwork.

The choice of Bairro Alto as a "laboratory" is related to its history in the context of the city and with the functional dynamics that are associated with it recently. Since the XIX that the presence of small industrial units (printing presses, manufacture of metal articles, furniture and publishing-related activities) and booths and intellectual meetings, of which the fado houses and the taverns are still references today, that the neighborhood assumes the specificity of its functions in the city as a whole. More recently, the exit of the press activities, with a long history in the neighborhood, left spaces empty that have been reconverted, giving this territory new uses: spaces of services, art galleries, theaters, bars and avant-garde shops are mixed today with the old associations and clubs that maintains the neighborhood traditions, the small grocery stores, the old barbers and the seamstresses. In addition to these dynamics of the economic fabric, changes in the social fabric are also associated with the arrival of new inhabitants (gentrification), and the increasing diversification and differentiation of social and cultural practices confirms this.

The methodological line of the work started with students being given the objectives of the fieldwork, as well as a description of how and when activities of preparation of the visit itself would take place. They were also informed about the correct procedures

8 With the collaboration of Célia Martins and Cristina Barbosa, at the time professors at the Lisbon School of Education. 
for data collecting that a functional survey imposes and the subsequent statistical and cartographic analysis of the survey, as well as analysis and evaluation of the results. The need to mobilize good motivation was fundamental to the success of fieldwork. To accomplish that, teachers gave some examples of recent episodes affecting the neighbourhood. At the same time students were invited to share their perceptions about socioeconomic characteristics of the local community being studied, trying to collect some previous ideas about the Bairro Alto. It was important to understand the general perception of the group of students about the area of research and connect it to the theoretical content. At this stage, it was important not to fall into the temptation to transmit or provide a high volume of information as it would be possible to find more during fieldwork.

Next, the urban area under study and its geographical location was identified, using the interactive Lisbon site and Google Maps (fig. 1), to establish a previous indirect contact with the reality to be studied, observing, for maps or satellite images, their urban morphology and delimiting the block / area on which the functional survey would be based (fig.2).

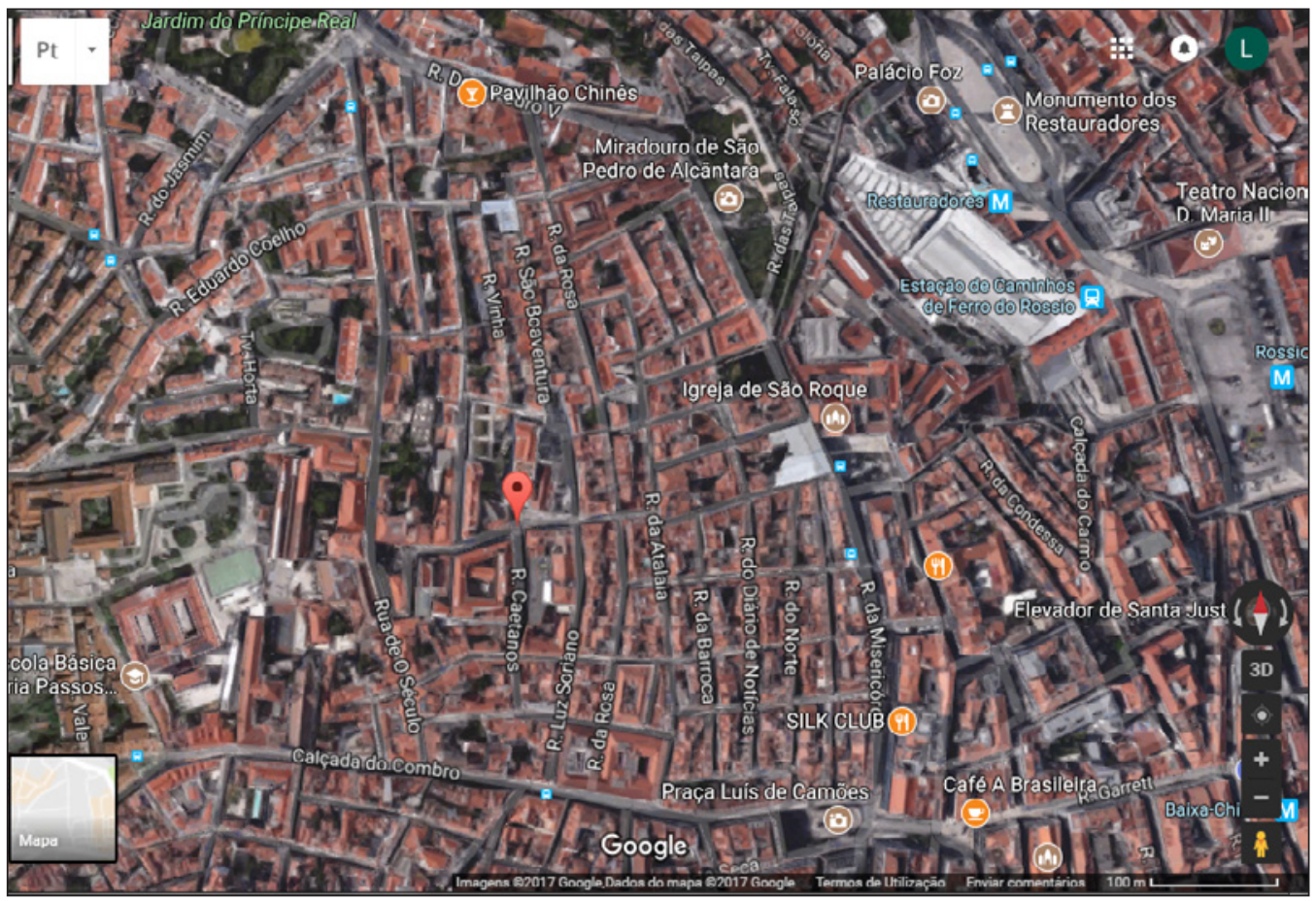

FiguRE 1. First approach to Bairro Alto by Google maps 


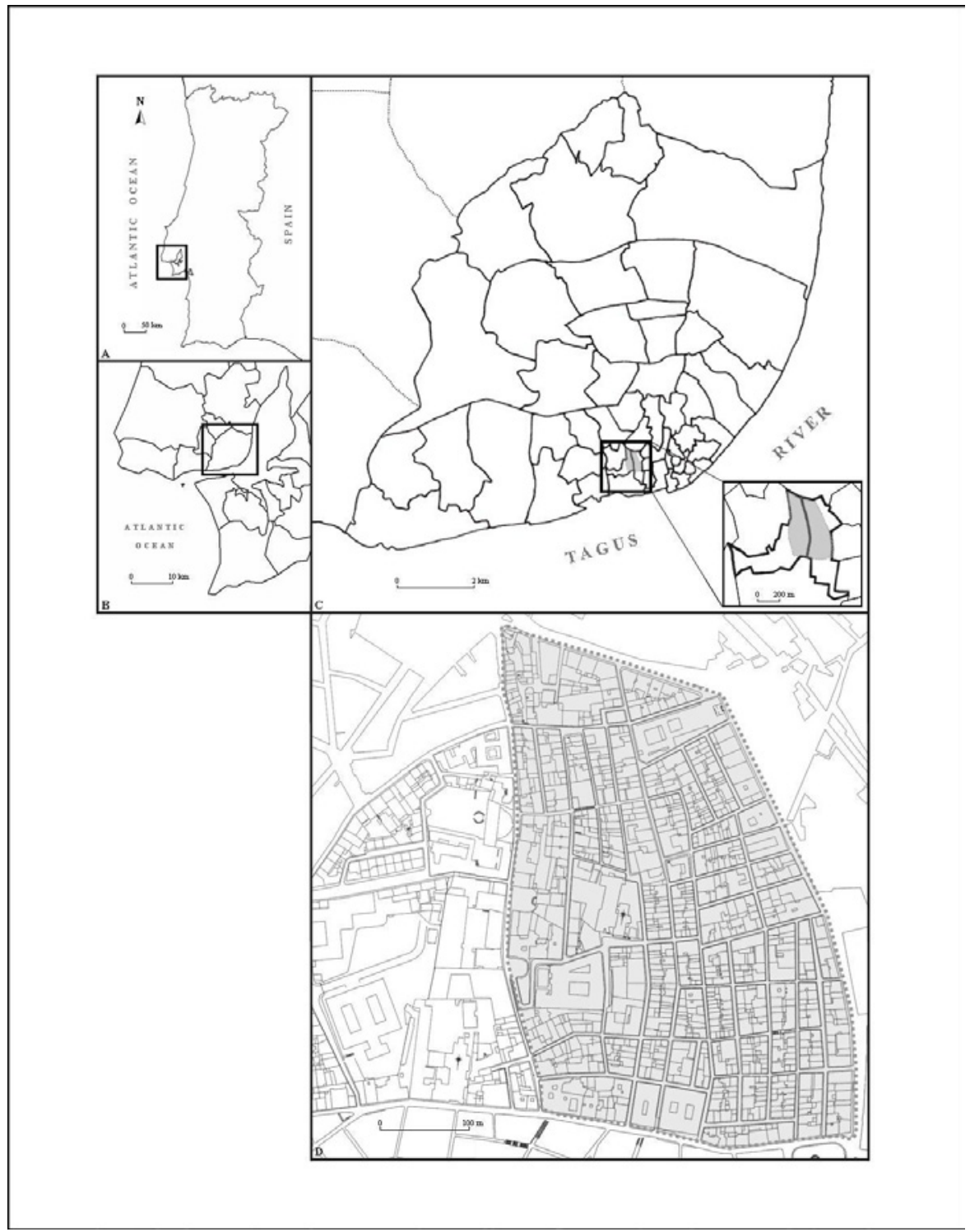

FIGURE 2. Block boundaries in the study area, Bairro Alto

On the ground, data collection was done using a functional survey form, where the economic activities / functions in the area under study should be identified according to a previously given classification. The information collected was organized according to the given classification and a cartography was built through appropriate visual variables (fig.3). 


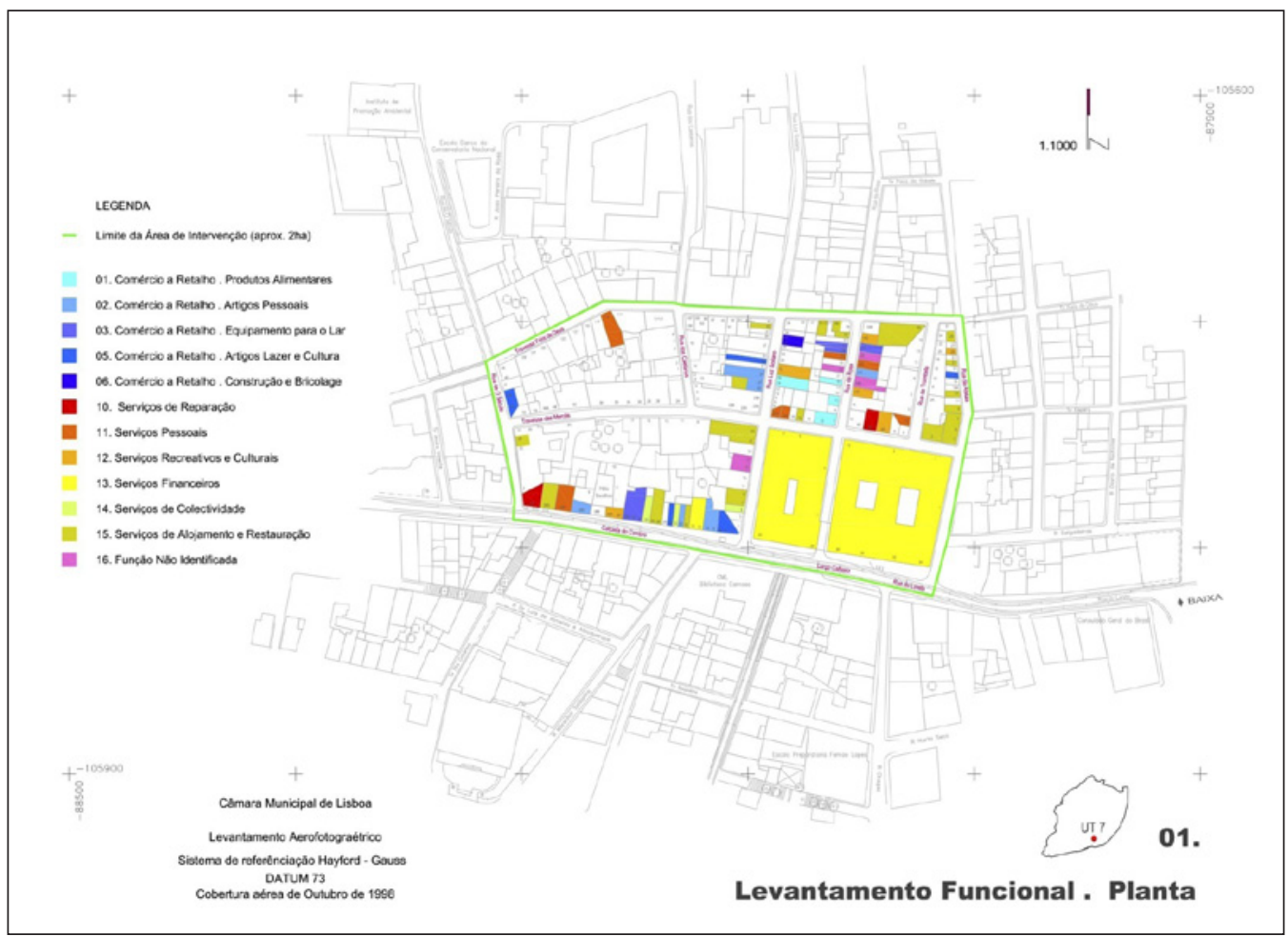

FIGURE 3. Example of functional plant performed by students

These data and more information collected in fieldwork was latter developed in class. These classes were organized to make sense of the data collected and several sources were mobilised such as literature review, statistical information, cartographic and photographic analysis of the area of study. The data were compiled and some explanatory hypotheses were formulated trying to identify the trends in terms of retail and services organization in the area being researched.

The analysis of the data and information was an important moment of knowledge consolidation and reconceptualization. It was also an important moment of skills development as the students tried to answer some geographical questions that were raised in the process of understanding the commercial tissue dynamics of the neighbourhood. Which were the dominant activities? Which were the rarest activities? How were they dispersed in area being studied? Why there was such a dispersion? What are the constraints and the most pressing opportunities for Bairro Alto's activities? These activities developed during two to three classes at the university, were the most significant for the students as it was later assessed. 
Cavalcanti (1998, 2008, 2012) and Mérenne-Schoumaker (2015) argue that the purpose of teaching Geography for young people and adults should be to help them form broader and more critical thinking and conceptions about the space category within a critical-social didactic, in which teaching-learning becomes a process of knowledge by the student, mediated by the teacher and by the content of the subject taught. It is also argued that learning is investigating. Here - and following the one mentioned in the previous point - the concept of research is adopted to designate the learning process, based on the development of the ordinary knowledge and the investigative strategies developed by the students. Research emerges as a key concept in the teaching-learning process and in the experience we bring here, we sought to stimulate it by local consultation by students of works, reports or other documents of interest to the history and geography of the city of Lisbon, in the Center of Lisbon Studies, in the municipal archives and in research in various dictionaries of the city of Lisbon, among other guides, as well as the stimulating field work done and the non-participant observation in the various visits to the neighborhood. The approaches related to school research are based on the fundamental principle that knowledge is operative, that is, the student builds his knowledge from his experiences and the concepts he already has, from the so-called previous ideas.

In the Cavalcanti line, but focusing now on the specificities of the students who attend the degree course in Basic Education, this research work in the city stimulated the mobilization of localization skills; of reading the territory from diverse representations; the construction of local exploration routes; collection, organization and processing of information from different sources; of graphical representation of the reality and of the understanding of the multiple factors that interfere in the dynamics of the places. In the case of young people with different backgrounds in previous training, contact with this work methodology allows, on the one hand, the widening of horizons of possibilities for geographic education and, on the other hand, the awareness of a practice that, as apprentices of educators / teachers should be able to mobilize with children who are taking their first steps in World Knowledge and / or the Local Environment Study.

\section{CONCLUSION}

Field work has always been an important teaching-learning methodology for school geography. It is through direct observation that the geographer collects much of the information that is subsequently compiled, correlated and generalized in a laboratory. For this reason, it is not strange that teachers of geography use it as a preferential strategy. As Alexandre and Diogo (1997) already pointed out in the 1990s, the certainties that teachers leave when they choose to carry out the fieldwork suggest that the teaching staff 
is fully aware of its pedagogical validity, something that does not always correspond to the truth, even because the practice has the weight of a tradition of decades.

For some time, the use of fieldwork appears to have been stripped of all other teachinglearning methodologies, namely the investigative method, and is often perceived as a playful and fun moment, resulting to the student only as a "liberation" of the class, without recognizing in it any relation between learning in and outside the classroom. In fact, the so-called "study visits", "excursions", among other forms of fieldwork, which traditionally presented a merely recreational nature, started to seek a stronger contact and link between school and the environment.

Field trips are important moments and means of mobilizing students' motivation for learning and developing a good teacher-student relationship. Besides the interaction among students and the socialization opportunity they provide, they can and should be used to promote learning. The use of field trips and fieldwork enhance the variety of teaching-learning methodologies that teachers can implement to promote meaningful learning within real contexts and through real problems.

To be well succeeded fieldwork must be carefully planned, it must involve in this preparation both the teacher and students. The implementation of a effective methodology of data collection, data organization, information analysis and presentation of the results of the study, as well as an assessment of the experience will allow the success of fieldwork in such a way that it contributes to effective learning. The key idea from which we started was that the fieldwork allowed a strong connection between theory and practice. More, it was also defined as an important activity in terms of skills development in different areas such as observation, analysis, location, orientation, critical thinking and research, being fundamental in geographic education.

It is important to emphasize that for these students of initial teaching training program, future teachers and educators therefore, the interactions experienced in the planning and implementation of the different tasks that make up the fieldwork themselves constitute opportunities for the development of geographical competences in different dimensions of knowledge and know-how geography that they should be able to transport to the classroom. Only by experiencing moments of field work, as trainees, will it be possible to develop the skills to be mobilized, later, to the children, the main ones involved in the work with the teacher / educator.

In summary, and reinforcing the opportunities for the development of geographical competences that derive from an effective practice of field work, the results of the courses carried out with these students in initial formation allow to affirm that they are better qualified for the development of localization skills and spatial orientation using different instruments; collection of information in different sources using various 
methods, techniques, procedures and instruments; landscape reading and knowledge of the characteristics and dynamics of places at different scales; mobilization of geographic vocabulary in the construction of knowledge and communication in Geography. These, developed along with the competences of knowing space but also develop a territorial citizenship, have already been widely discussed in this text.

Fieldwork activities have very specific pedagogical characteristics, as we have demonstrated in the learning experience described above. In spite of this, some critical analysis of current teaching-learning models remains to be done as well as a consideration of how fieldwork has been used within the different paradigms of geographical science. Having these in mind, we have tried to problematize the role of the fieldwork as a teachinglearning strategy. We have also framed this learning activity into the context of theoretical reflections and practical options for geographical education, mainly within a socio-critical perspective, problematizing real questions and stimulating critical spatial thinking.

\section{REFERENCES}

Alcântara V. (2015). A importância das atividades de campo no ensino da geografia e na educação ambiental no desenvolvimento da consciência crítica do aluno. Anais do II Encontro Fluminense de Uso Público em Unidades de Conservação. Turismo, recreação e educação: caminhos que se cruzam nos parques, Rio de Janeiro.

Alentejano P., Rocha-Leão O. (2006). “Trabalho de campo: uma ferramenta essencial para os geógrafos ou um instrumento banalizado?". Boletim Paulista de Geografia, 84: 51-68.

Alexandre F., Diogo J. (1997). Didáctica da Geografia. Contributos para uma Educação no Ambiente. Texto editora, Lisboa.

Bado S. (2009). Desafios da Geografia: A Cidade como Conteúdo Escolar no Ensino Médio. Tese de doutoramento. Instituto de Geociências da Universidade Federal do Rio Grande do Sul, Porto Alegre.

Bailey P. (1985). Didactica de la Geografía. Editorial Cincel, Madrid.

Benejam P. (1992). "La didàctica de la geografia des de la perspectiva construtivista". Documents d'Anàlisi Geogràphicà, 21: 35-52.

Benejam P. (1996). "La didática de la geografia en el contexto del pensamiento de finales del siglo XX. La influencia del postmodernismo”. IBER Didactica de las Ciencias Sociales, Geografia e Historia, 9: 7-14.

Bento I., Cavalcanti L. (2009). "Saberes e práticas de professores de geografia referentes ao conteúdo cidade no cotidiano escola"r. $10^{\circ}$ Encontro Nacional de Prática de Ensino em Geografia, Porto Alegre. 
Cachinho H., Reis J. (1991). "Geografia escolar: (re)pensar e (re)agir". Finisterra, 26(52): 429-443.

Cachinho H. (2002). "Geografia escolar: orientação teórica e praxis didática”. Inforgeo, 15: 69-90.

Cachinho H. (2012). "Criando experiências de aprendizagem significativas: do potencial da aprendizagem baseada em problemas". El Hombre y la Máquina, 40: 58-67.

Cachinho H. (2017). "Criar asas: dos desafios da formação de professores de geografia na pós-modernidade". Revista de Educação Geográfica, 1: 9-19.

Canário R. (1992). "O Estabelecimento de Ensino no Contexto Local”. In Canário R (org.) Inovação e Projecto Educativo de Escola. EDUCA, Faculdade de Psicologia e de Ciências da Educação da Universidade de Lisboa, Lisboa: 57-86.

Canário R. (2005). O que é a Escola? Porto Editora, Porto.

Carlos A.F. (1999). "Apresentando a metrópole na sala de aula”. In Carlos A F (eds) A Geografia na Sala de Aula. Contexto, São Paulo: 79-91.

Castellar S., Cavalcanti L., Callai H. (2012). Didática da Geografia: Aportes Teóricos e Metodológicos. Xamã Editora, São Paulo.

Cavalcanti L. (1998). Geografia, Escola e Construção de Conhecimentos. Papirus, São Paulo.

Cavalcanti L. (2008). A Geografia Escolar e a Cidade: Ensaios sobre o Ensino de Geografia para a Vida Urbana Cotidiana. Papirus, São Paulo.

Cavalcanti L. (2012). O Ensino de Geografia na Escola. Papirus, São Paulo.

Claudino S. (2015). "Projecto "Nós Propomos!": tentar mudar a educação geográfica em pequenos passos". In Sebastiá Alcaraz R; Tonda Monllor E (eds) La Investigación e Innovación en la Enseñanza de la Geografía. Universidad de Alicante, San Vicente del Raspeig: 661-667.

Debesse-Arviset M. (1978). A Educação Geográfica na Escola. Almedina, Coimbra.

Dourado J (2013) "Geografia "fora" da sala de aula: a importância do trabalho de campo para a geografia agrária”. Campo-Território, 8(15): 1-22.

Esteves H. (2010). Os Percursos da Cidadania na Geografia Escolar Portuguesa. Tese de doutoramento. Instituto de Geografia e Ordenamento do Território da Universidade de Lisboa, Lisboa.

Evangelista H. (2014). Aspectos Históricos da Geografia Brasileira. Letra Capital, Rio de Janeiro.

Ferreira C. (1990). A Evolução do Pensamento Geográfico. Gradiva, Lisboa. 
Ferreira C. (1995). A Utilização do Trabalho de Campo nas Estratégias de EnsinoAprendizagem em Geografia. Tese de mestrado. Faculdade de Psicologia e de Ciências da Educação da Universidade de Lisboa, Lisboa.

Ferreira N., Martins C., Hortas M.J., Dias A. (2011). Do património local ao currículo nacional: análise de projetos no âmbito das metodologias de ensino de História e Geografia para o $1^{\circ}$ e $2^{\circ}$ CEB. Atas do $V$ Encontro do CIED "Escola $e$ Comunidade”, Escola Superior de Educação de Lisboa, Lisboa: 499-512.

Galvani E., Beserra de Lima N. (2008). "O trabalho de campo como recurso didático na Geografia”. GEOUSP, Espaço e Tempo, 24: 152-163.

Hugonie G. (1989). "Enseigner la géographie actuelle dans les lycées”. L' Espace Geógraphique, 18(2): 129-133.

Hugonie G. (1992). Pratiquer la géographie au collège. Armand Colin, Paris.

Hugonie G. (1997). "Les élèves de collège et de lycée et la notion de milieu". Bulletin de l'Association de Geographes Français, 74(3): 282-288.

IGU-CGE (2015). International Declaration on Research in Geography Education. International Geographical Union Commission on Geographical Education, Moscovo.

Job D. (2000). New Directions in Geographical Fieldwork. Cambridge University Press, Cambridge.

Justen-Zancanaro R., Carneiro, C. (2012). "Trabalhos de campo na disciplina de Geografia". Terrae, 9: 49-60.

Kaiser B. (2006). O geógrafo e a pesquisa de campo. "Boletim Paulista de Geografia”, 84: 93-104.

Lacerda E., Borges F., Oliveira D. (2015). "A importância do trabalho de campo em geografía”. Okara, Geografia em Debate, 9(1): 178-192.

Lacoste Y. (2006). "A pesquisa e o trabalho de campo: um problema político para os pesquisadores, estudantes e cidadãos". Boletim Paulista de Geografia, 84: 77-92.

Lambert D., Balderstone D. (2000). Learning to Teach Geography in the Secondary School. A Companion to School Experience. Routledge Falmer, Londres.

Matheus E. (2007). "O que há por detrás de uma panela? Uma atividade de campo como trajetória a um olhar geográfico". In Rego N, Castrogiovanni A, Kaercher N (eds) Geografia: Práticas Pedagógicas para o Ensino Médio. Artmed, Porto Alegre: 135-148.

Mérenne-Schoumaker B. (1985). "Savoir Penser l'Espace. Pour un Renouveau Conceptuel et Méthodologique de l'Enseinement de la Géographie dans le Secondaire”. L'Information Geógraphique, 49: 151-160. 
Mérenne-Schoumaker B. (1999). Didáctica da Geografia. Edições Asa, Porto.

Mérenne-Schoumaker B. (2015). "Former ses élèves à l'abstraction en géographie". Didáctica Geográfica, 16: 25-43.

Morais E., Cavalcanti L. (2011). “A Cidade, os sujeitos e as suas práticas espaciais cotidianas". In Morais E, Cavalcanti L (org.) A Cidade e os seus Sujeitos. Editora Vieira, Goiânia: 13-30.

Neves K. (2015). Os Trabalhos de Campo no Ensino da Geografia: Reflexões sobre a Prática Docente na Educação Básica. Editus, Ilhéus, Bahia.

Ogallar A. (1996). "El trabajo de campo y las excursiones". In Jiménez A, Marrón Gaite M J (eds) Enseñar Geografía. De la Teoría a la Práctica. Editorial Sintesis, Madrid: 159-184.

Oliveira K. (2008). Saberes Docentes e a Geografia Urbana Escolar. Tese de doutoramento. Instituto de Estudos Sócio-Ambientais da Universidade Federal de Goiás, Goiânia.

Graves N. (1978). "Métodos de ensino: observação directa". In Graves N (eds) Manual da Unesco para o Ensino da Geografia. Editorial Estampa, Lisboa: 71-124.

Plans P. (1967). Didáctica da Geografia. Livraria Civilização, Porto.

Reis J. (2002). "Educação Geográfica e Cidadania: uma missão possível". In Barata Salgueiro, T (coord.) Olhares sobre o Território e a Espacialidade. Estudos de Geografia Humana e Regional, nº45, Centro de Estudos Geográficos da Universidade de Lisboa, Lisboa: 95-106.

Rodrigues A., Otaviano C. (2001). "Guia metodológico de trabalho de campo em Geografia”. Geografia, Londrina, 10(1): 35-43.

Santos L., Cruz J. (1995). Guia de Recursos: A Escola e o Meio, Livro de Apoio ao trabalho de Professores e Alunos. Edições Asa, Porto.

Serrano-Velarde K. (2010). "New Challenges to Higher Education: Managing the Complexities of a Globalised Society". In Bergan S, Damian R (ed) Higher Education for Modern societies: Competences and Values. Council of Europe Publishing, Estrasburgo: 39-48.

Serpa A. (2006). "O trabalho de campo em Geografia: uma abordagem teóricometodológica”. Boletim Paulista de Geografia, 84: 7-24.

Silva F. (2004). "Aproximar sem reduzir: as derivas e a pesquisa de campo em geografia urbana”. Espaço e Tempo, 15: 139-149.

Souto González X. et al. (1994a). El Estudio Geográfico de los Problemas Urbanos. Orientación Teórica y Praxis Didática. Nau Llibres, Valencia. 
Souto González, X. et al. (1994b). Viviendas y Ciudades. Nau Llibres, Valencia.

Souto González, X. (1998). Didáctica de la Geografia. Problemas Sociales y Conocimiente del Medio. Ediciones del Serbal, Barcelona.

Souto González, X. (2002). "A didáctica da geografia: dúvidas, certezas e compromisso social dos professores". Inforgeo, 15: 21-42.

Souto González, X. (2017). "Los métodos didácticos en la enseñanza del espácio geográfico". In Sebastiá Alcaraz R; Tonda Monllor E (eds) Enseñanza y Aprendizaje de la Geografía para el siglo XXI. Universidad de Alicante, San Vicente del Raspeig: 73-96.

Souza S., Chiapetti R. (2012). "O geógrafo e a pesquisa de campo". Revista de Ensino da Geografia, 3(4): 3-22.

Straforini R. (2008). Ensinar Geografia: O Desafio da Totalidade-Mundo nas Séries Iniciais. AnnaBlume, São Paulo.

Zabalza M. (1992a). Planificação e Desenvolvimento Curricular na Escola. Edições Asa, Rio Tinto.

Zabalza M. (1992b). "Do Currículo ao Projecto de Escola”. In Canário R (org.) Inovação e Projecto Educativo de Escola. EDUCA, Faculdade de Psicologia e de Ciências da Educação da Universidade de Lisboa, Lisboa: 87-108.

Zabalza M. (2013). "A docência no ensino superior e metodologias de avaliação". II Jornadas Pedagógicas da Escola Superior de Comunicação Social. Lisboa. 
